NOYAL

隹

CAMDEN FIFTH SERIES

The Letters of Lord Burghley, William Cecil, to his Son Sir Robert Cecil, 1593-1598

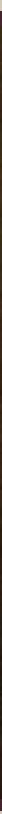




\section{THE LETTERS OF LORD \\ BURGHLEY, WILLIAM GEGIL, TO \\ HIS SON SIR ROBERT GEGIL, \\ I593-I598 $^{-1}$}




\title{
THE LETTERS OF LORD BURGHLEY, WILLIAM GEGIL, TO HIS SON SIR ROBERT GEGIL, I593-I598
}

\author{
edited by \\ WILLIAM ACRES
}

CAMDEN FIFTH SERIES

Volume 53

\begin{abstract}
CAMBRIDGE UNIVERSITY PRESS

FOR THE ROYAL HISTORICAL SOCIETY

University College London, Gower Street, London WCI 6BT 2017
\end{abstract}


Published by the Press Syndicate of the University of Cambridge

University Printing House, Shaftesbury Road, Cambridge CB2 8BS, United Kingdom

I Liberty Plaza, Floor 2o, New York, NY ıooo6, USA

477 Williamstown Road, Port Melbourne, VIC 3207 , Australia

C/Orense, 4, Planta I3, 28020 Madrid, Spain

Lower Ground Floor, Nautica Building, The Water Club,

Beach Road, Granger Bay, 8005 Cape Town, South Africa

(C) Royal Historical Society 2017

First published 2017

A catalogue record for this book is available from the British Library

ISBN 978I 108424554 hardback

S UBSGRIPTIONS. The serial publications of the Royal Historical Society, Royal Historical Society Transactions (ISSN oo8o-440I) and Camden Fifth Series (ISSN og6oII63) volumes, may be purchased together on annual subscription. The 2017 subscription price, which includes print and electronic access (but not VAT), is $\mathcal{E}_{185}$ (US \$309 in the USA, Canada, and Mexico) and includes Camden Fifth Series, volumes 52 and 53 and Transactions Sixth Series, volume 27 (published in December). The electroniconly price available to institutional subscribes is $\mathcal{E}_{155}$ (US \$259 in the USA, Canada, and Mexico). Japanese prices are available from Kinokuniya Company Ltd, P.O. Box 55, Chitose, Tokyo I56, Japan. EU subscribers (outside the UK) who are not registered for VAT should add VAT at their country's rate. VAT registered subscribers should provide their VAT registration number. Prices include delivery by air.

Subscription orders, which must be accompanied by payment, may be sent to a bookseller, subscription agent, or direct to the publisher: Cambridge University Press, University Printing House, Shaftesbury Road, Cambridge CB2 8BS, UK; or in the USA, Canada, and Mexico: Cambridge University Press, Journals Fulfillment Department, I Liberty Plaza, Floor 20, New York, NY iooo6, USA.

SINGLE VOLUMES AND BACK VOLUMES. A list of Royal Historical Society volumes available from Cambridge University Press may be obtained from the Humanities Marketing Department at the address above.

Printed in the UK by Bell \& Bain Ltd.

The original publication contained the wrong ISBN number. The number shown above is correct. 


\section{GONTENTS}

PREFACE vii

LIST OF ABBREVIATIONS ix

INTRODUGTION I

THE LETTERS OF LORD BURGHLEY, WILLIAM CEGIL, TO HIS SON SIR ROBERT CECIL, I593-I598 87

BIBLIOGRAPHY 295

$\begin{array}{ll}\text { INDEX } & 305\end{array}$ 
This volume is dedicated to Professor Paul Christianson. 